\title{
THE CAP GREENING EFFECTS - THE POLISH EXPERIENCE
}

Wioletta WRZASZCZ, Institute of Agricultural and Food Economics - National Research Institute, Świętokrzyska str. 20, 00-002 Warsaw, Poland, wrzaszcz@ierigz.waw.pl

In 2015 greening requirements were implemented. All farmers entitled to the Single Area Payment are obliged to implement greening, depending on agricultural surface and structure. Presently, $30 \%$ of the national financial envelope is connected with greening. Legal rules obliged farmers to more environmental friendly farms`organization. The European Commission regulations indicated the importance of crop diversification in the context of soil quality improvement, the maintenance of permanent grasslands in order to ensure the carbon sequestration, soil protection and biodiversity, as well as the maintenance of ecological focus areas that guarantees biodiversity at the farm level. The aim of the paper is to present the farms organizational changes and outcomes after the implementation of greening mechanism. Polish FADN data were used for 2014 and 2015, that covered 5.7 thousand farms. The research results indicated the farms ' adaptation to greening requirements. The production capacity of the analysed FADN farms did not decrease after the greening mechanism introduction. Farmers combined production objectives with environmental ones, that was the result of farms ' proper organization and enlarging agricultural land. The scope of changes introduced in plant production referring to the greening requirements was insignificant and concerned mainly larger farms (with arable land area of 15 ha and more). Farmers introduced the required organizational changes smoothly, mainly by increasing area under leguminous and papilionaceous plants. The environment-friendly farms' organization before greening introduction facilitated their adaptation in 2015. In the short term, greening doesn't cause negative productive and economic outcomes. In the longer perspective, greening environmental effects should contribute to factor productivity increase.

\section{Keywords: Greening, the Common Agricultural Policy, Direct payments, Natural environment, FADN, Poland}

\section{INTRODUCTION}

The European Union is directed towards sustainable development of agriculture and rural areas, that is reflected in the Common Agricultural Policy instruments (Kociszewski, 2014; Krzyżanowski, 2015). Under the new direct payment scheme an obligation has been introduced since 2015 to apply agricultural practices favourable for climate and environment, the socalled greening. This requirement has allowed farmers to get total support within the framework of direct payments. Conditional farms`subsidising was compatible with the provider gets principle (Mauerhofer, Hubacek, Coleby, 2013).

In the context of greening, many substitute agricultural practices were included, that are selected by the farmer (Hart, 2015). All farmers entitled to the Single Area Payment Scheme in 2015 are obliged to implement greening, depending on agricultural surface and structure. Presently, 30\% of the national financial envelope is connected with greening (Ministry of Agricuture and Rural Development, 2015) ${ }^{1}$. Greening practices were specified in the European Commission regulations, which indicate the importance of crop diversification in the context of soil quality improvement, the maintenance of permanent grasslands in order to ensure the carbon sequestration, soil protection and biodiversity, as well as the maintenance of ecological focus areas that guarantees biodiversity at the farm level ${ }^{2}$.

Depending on the area of arable land used and the share of permanent grassland, farmers are required to follow one, two or three greening practices. Greening practices in Poland include: diversification of crops (applicable to farms with an arable land area of 10 ha or more), (b) maintenance of Ecological Focus Areas (EFA) on at least 5\% of arable land (applies to farms with an arable land area of 15 ha or more), (c) maintenance of permanent grassland (the ratio of grassland to total agricultural area may not decrease by more than 5\% compared to the reference ratio) (Ministry of Agriculture and Rural Development, 2015). The requirement to diversify plants binds farms to grow at least 2-3 different crops on arable land (depending on the land area), specifying their share in the cropping pattern. Crops may be diversified also by using an equivalent practice applied as part of the agri-environment and climate measure under the RDP $2014-$

${ }^{1}$ In 2015, the rate of greening payment amounted to 72 EUR/ha.

${ }^{2}$ Comparison of greening effects in different European countries is presented in: (EC, 2016; EC, 2017; Hart, Baldock, Buckwell, 2016).

Copyright (C) 2017 The Authors. Published by Aleksandras Stulginskis University. This is an open-access article distributed under the terms of the Creative Commons Attribution License (CC-BY 4.0), which permits unrestricted use, distribution, and reproduction in any medium, provided the original author and source are credited. 
$2020^{3}$. As regards the EFA maintenance requirement, its fulfilment entails the maintenance of landscape, forest and agricultural features. Agricultural features include fallow land and the cultivation of plants that favorably affect soil condition, including the cultivation of nitrogen-fixing plants in the main crop, also in the form of catch crops and companion crops ${ }^{4}$.

EU regulations provide also for a number of exemptions from the obligation to implement greening mechanism. Farms, in which over $75 \%$ of agricultural land is permanent grassland or farms with a high (over $75 \%$ ) share of arable land used to produce grass or other herbaceous fodder plants, or with fallow land, due to a favourable environmental impact, are exempt from the requirement to diversify crops or maintain EFAs ${ }^{5}$. Farms participating in the small farm scheme, in spite of being exempt from greening requirement, are entitled to receive this payment. Greening payments are automatically granted to farmers pursuing agricultural production in accordance with the ecological agriculture rules ${ }^{6}$ (Agency for Restructuring and Modernization of Agriculture, 2015; Direct Payments Department, 2016; Ministry of Agriculture and Rural Development, 2015).

The aim of the paper is to present farms' organizational changes and outcomes after the introduction of greening requirements.

\section{RESEARCH METHOD}

The paper is based on a panel of 5.7 thousand private farms included in the Farm Accountancy Data Network (FADN), with an area of at least 10 ha of arable land. These farms kept agricultural accounting both in 2014 and 2015. The study does not cover farms exempt from greening requirement (farms with an area of arable land below 10 ha), or these that apply equivalent practices to greening ones. The paper presents the organization and outcomes of farms before and after the amendment to legal provisions binding on farmers interested in getting full direct support. The surveyed farm panel was divided into two groups, i.e. farms with an area of arable land 10-15 ha (these farms were obliged to meet the crop diversification requirement) and farms with an area of arable land of 15 ha and more (these farms were also obliged to meet the EFA maintenance requirement).

Furthermore, agricultural practices related to the maintenance of EFA were identified based on the FADN data for 2015. The population of farms with EFAs numbered 4.7 thousand farms ${ }^{7}$.

There was the comparative analysis of statistical data used (based on original/source data, not published in the official publications of FADN Standard Results). Statistical data were derived from the FADN accounting books, that were collected by face-to-face interviews, organised by FADN Liaison Agency in Poland (Institute of Agricultural and Food Economics-National Research Institute) in cooperation with agricultural advisors from 16 Voivodship Agricultural Advisory Centers. In order to verify the effects of greening in farms`organisation in the first year of the requirement application, there was used indicator analysis based on the legal requirements associated with crop diversification and the maintenance of ecological focus areas.

\section{RESULTS AND DISCUSIONS}

\section{Land use in the context of greening requirements}

The analysed FADN set was dominated by farms with an arable land area of 15 ha and more (77\%). These farms were assigned particular importance in the implementation of environment-friendly practices, in particular these related to the maintenance of EFAs (Table 1). As regards the analysed panel, farms with an arable land area of 15 ha and more hold as much as $92 \%$ of the total area of arable land.

The average area of the analysed farms was 44 ha of agricultural land (Table 1). Comparing the situation in 2015 to that in 2014, it can be inferred that the production capacity of farms bound by the greening requirement did not change, which applies both to the smaller and larger ones. The average area of smaller farms was 19 ha, while that of larger farms - almost 52 ha of agricultural land. These two groups of farms showed considerable differences in terms of stocking density, which was much lower in larger farms - by one third. This proves the weakening relation between plant and animal production with farms` area increase. A higher stocking density in smaller farms, hence greater production of natural fertilizers, makes it possible to balance the plant demand for macronutrients with the use of fertilizers produced by the farm itself, while improving the water and soil conditions.

In the analysed period, there was no change in the average farms`area of arable land (Table 2). In the case of permanent grassland, a 3\% decrease was recorded, but it did not exceed the limit provided for in legal provisions (i.e. $5 \%$ ). In 2015, a significant increase in land lying fallow (45\%) was reported. However, this area was physically small and

\footnotetext{
3 Ministry of Agriculture and Rural Development, Rural Development Programme for 2014-2020, see: http://www.minrol.gov.pl/Wsparcierolnictwa/Program-Rozwoju-Obszarow-Wiejskich-2014-2020.

${ }^{4}$ EFA elements in Poland: EFA1. fallow land, EFA2. hedges, EFA3. single trees, EFA4. trees in line, EFA5. trees in group, EFA6. field margins, EFA7. ponds, EFA8. ditches, EFA9. buffer strips, EFA10. land strips without production along forest, EFA11. land strips qualified for the payment, located along forest edges, EFA12. short-rotation coppice, EFA13. afforested areas, EFA14a. stubble catch crops, EFA14b. winter catch crops, EFA 14c. undersown grasses, EFA15. nitrogen-fixing crops (Agency for Restructuring and Modernization of Agriculture, 2015). The selection of the EFA elements is the responsibility of individual EU countries (EC, 2017).

${ }^{5}$ Provided that the remaining arable land area does not exceed 30 ha.

${ }^{6}$ Pursuant to Article 29(1) of Council Regulation (WE) No 834/2007.

${ }^{7}$ Since 2015, the detailed list of practices pursued in farms under the greening mechanism has been registered in the FADN.
} 
accounted for only $0.5 \%$ of the arable land area. The increase in fallow land in the average farm was not accompanied with a reduction in the sown area on arable land. Farmers increased their farms with areas which had not been used for agricultural purposes before, either by purchase or lease.

Table 1. Farms` production potential (per an average farm)

\begin{tabular}{|c|c|c|c|c|c|c|c|c|c|c|}
\hline \multirow{2}{*}{ No. } & \multirow{2}{*}{ Specification } & 2014 & 2015 & \multirow{2}{*}{$\begin{array}{c}-15 / 14 \\
\%\end{array}$} & 2014 & 2015 & \multirow{2}{*}{$\frac{15 / 14}{\%}$} & 2014 & 2015 & \multirow{2}{*}{$\frac{15 / 14}{\%}$} \\
\hline & & \multicolumn{2}{|c|}{ Total } & & \multicolumn{2}{|c|}{ 10-15 ha } & & \multicolumn{2}{|c|}{$\geq 15$ ha } & \\
\hline 1 & Farms`number & 5705 & 5705 & 100 & 1297 & 1297 & 100 & 4408 & 4408 & 100 \\
\hline 2 & Agricultural lanc & 44.12 & 44.44 & 101 & 19.27 & 19.12 & 99 & 51.44 & 51.89 & 101 \\
\hline 3 & Labour int & 2.00 & 1.99 & 99 & 1.80 & 1.79 & 99 & 2.06 & 2.05 & 99 \\
\hline 4 & Livestock [LU/farm] & 33.19 & 32.63 & 98 & 20.78 & 21.08 & 101 & 36.84 & 36.02 & 98 \\
\hline 5 & Livestock [LU/ha] & 0.75 & 0.73 & 98 & 1.08 & 1.10 & 102 & 0.72 & 0.69 & 98 \\
\hline 6 & Assets [thous. EUR/farm] & 398 & 403 & 101 & 194 & 192 & 99 & 459 & 464 & 101 \\
\hline
\end{tabular}

* I AWU (Annual Work Unit) is equivalent to full-time own and paid labour, i.e. 2.120 hours of work a year. 1 LU is a standard unit of farm animals weighing $500 \mathrm{~kg}$. Source: Own study based on FADN data.

Table 2. Land use [thous. ha]

Table 2. Land use [thous. ha]
\begin{tabular}{|c|l|r|r|r|r|r|r|r|r|r|}
\hline \multirow{2}{*}{ No. Specification } & \multicolumn{2}{|c|}{2014} & 2015 & $15 / 14$ & 2014 & 2015 & $15 / 14$ & 2014 & 2015 & $15 / 14$ \\
\cline { 2 - 9 } & & \multicolumn{2}{|c|}{ Total } & \multicolumn{1}{c}{$\%$} & $10-15$ ha & \multicolumn{1}{c}{$\%$} & $\geq 15$ ha & $\%$ \\
\hline 1 & Agricultural land & 251.7 & 253.5 & 101 & 25.0 & 24.8 & 99 & 226.7 & 228.7 & 101 \\
2 & - Arable land & 225.4 & 227.9 & 101 & 19.5 & 19.3 & 99 & 205.9 & 208.6 & 101 \\
3 & --Fallow land & 1.1 & 1.6 & 145 & 0.1 & 0.1 & 117 & 1.0 & 1.5 & 149 \\
4 & - Grassland & 25.3 & 24.6 & 97 & 5.2 & 5.2 & 100 & 20.1 & 19.5 & 97 \\
\hline 5 & Cereal & 150.20 & 147.26 & 98 & 13.58 & 13.18 & 97 & 136.62 & 134.09 & 98 \\
6 & Pulses for grain & 6.70 & 12.14 & 181 & 0.40 & 0.68 & 173 & 6.31 & 11.46 & 182 \\
7 & -edible & 0.48 & 1.45 & 304 & 0.04 & 0.11 & 281 & 0.44 & 1.33 & 306 \\
8 & -fodder & 3.17 & 7.90 & 249 & 0.20 & 0.41 & 209 & 2.98 & 7.49 & 252 \\
9 & -- field pea & 0.43 & 1.22 & 285 & 0.05 & 0.07 & 153 & 0.38 & 1.15 & 301 \\
10 & -- horse bean & 0.26 & 0.85 & 332 & 0.02 & 0.05 & 217 & 0.23 & 0.80 & 343 \\
11 & --sweet lupine & 2.14 & 5.16 & 241 & 0.09 & 0.23 & 264 & 2.06 & 4.93 & 240 \\
12 & - pulse mixes with others & 3.05 & 2.79 & 92 & 0.16 & 0.16 & 100 & 2.89 & 2.63 & 91 \\
13 & Industrial & 39.03 & 37.95 & 97 & 1.20 & 1.15 & 96 & 37.82 & 36.80 & 97 \\
14 & Potatoes & 4.01 & 3.98 & 99 & 0.62 & 0.55 & 88 & 3.39 & 3.43 & 101 \\
16 & Fodder & 20.33 & 22.14 & 109 & 3.07 & 3.21 & 104 & 17.26 & 18.93 & 110 \\
16 & - grasses & 2.89 & 3.45 & 119 & 0.51 & 0.61 & 121 & 2.38 & 2.83 & 119 \\
14 & - pulses & 0.13 & 0.22 & 174 & 0.03 & 0.02 & 75 & 0.10 & 0.20 & 201 \\
18 & - papilionaceous & 0.98 & 1.58 & 161 & 0.14 & 0.20 & 136 & 0.84 & 1.38 & 165 \\
\hline 19 & Winter crops & 123.67 & 122.46 & 99 & 8.06 & 7.80 & 97 & 115.61 & 114.66 & 99 \\
20 & Catch crops & 5.70 & 11.66 & 204 & 0.39 & 0.32 & 82 & 5.32 & 11.34 & 213 \\
\hline
\end{tabular}

Source: Own study based on FADN data.

The two identified groups of farms, the smaller ones (10-15 ha of arable land) and the larger ones (arable land area of 15 ha and more) showed significant differences as regards land use. In the case of smaller farms, the area of land lying fallow and its change was small and the sown area on arable land was reduced insignificantly. As regards the larger farms, the area of arable land increased, including land lying fallow (by almost 50\%). In these farms, additional areas of land started to be used in 2015. The increase in this area can be associated with larger farms' adaptation to meet the EFA maintenance requirement. This situation may be due to legal regulations, as fallow land is one of the elements of EFAs. In order to ensure the adequate pro-ecological area, farmers would increase their farms with additional fallow land, not reducing the area intended for plant production.

Meeting the crop diversification requirement and the EFA maintenance requirement entails a specific pattern of cultivated plants. Incorporating winter and spring crops in the crop rotation significantly facilitates the fulfilment of the crop diversification requirement (while protecting soil against erosion in winter). As indicated by the presented data (Table 3), the analysed Polish farms, used a significant part of their land, both in 2014 and 2015, for growing winter crops (their share in the average farm accounted for more than a half of the sown area on arable land, and this was 54\% and $55 \%$, respectively in 2014 and 2015). Consequently, already a year before the crop diversification requirement was introduced, the organization of farms complied with it to a large extent. A more favourable organization of plant production in this respect could be observed in larger farms. There were significantly more winter crops in farms with an arable land area of 15 ha and more than in these with an arable land area of 10-15 ha (in 2015, the share of the area under winter crops in these two groups of farms accounted for $55 \%$ and $41 \%$, respectively). In both cases the area under these crops was significant and there was no increase in it in the analysed period (Table 2). The status quo as regards the area under winter crops was preserved, which should be positively assessed in the context of greening. There is no need to expect a further increase in the area under winter crops, as it is large enough - both in smaller and larger farms.

The cropping pattern in FADN farms is dominated by cereals with a $65 \%$ share, followed by industrial crops which account for $17 \%$ of the total crop area (as of 2017, Table 3). Analysing the cropping pattern in the average farm, it can be concluded that the share of remaining crops, including crops improving soil structure, i.e. leguminous and papilionaceous crops, is negligible and accounts for a few percent only. Leguminous and papilionaceous crops, both 
edible and fodder ones, are, however, a very important element of the cropping pattern, which has beneficial effects as regards the amount of soil organic matter, and consequently, soil productivity. This justifies inclusion of these plants in EFAs. Comparing the situation in 2015 with that in 2014, it should be noted that the area sown with leguminous crops increased sharply, especially in larger farms (Table 2). The area sown with edible leguminous plants and that sown with fodder leguminous plants increased by 3 and 2.5 times, respectively, while the area sown with leguminous crops mixed with other plants slightly decreased. These changes occurred both in smaller farms, which chose leguminous as a crop diversification element, and in larger ones, which were also obliged to maintain EFAs.

Fodder plants, including leguminous and papilionaceous plants, were another important element of the cropping pattern, as the area under these plants increased more than 1.5 times. Farmers increased in particular the area sown with cereals and cereals mixed with other plants intended for green feed. This area was increased to a greater extent by users of farms with an arable land area of 15 ha and more. The aforementioned results reflect the impact of the legislation relating to greening, including that related strictly to the maintenance of EFAs, on decisions taken by farmers as regards the area sown with plants improving soil structure.

Table 3. Crops structure $(\%)$

\begin{tabular}{|c|c|c|c|c|c|c|c|}
\hline \multirow{2}{*}{ No. } & \multirow{2}{*}{ Specification } & \multirow{2}{*}{2014} & \multirow{2}{*}{2015} & 2014 & 2015 & 2014 & 2015 \\
\hline & & & & \multicolumn{2}{|c|}{$10-15$ ha } & \multicolumn{2}{|c|}{$\geq 15$ ha } \\
\hline 1 & Cereal & 66.97 & 65.10 & 70.20 & 68.93 & 66.67 & 64.75 \\
\hline 2 & Pulses for grain & 2.99 & 5.37 & 2.05 & 3.57 & 3.08 & 5.53 \\
\hline 3 & - edible & 0.21 & 0.64 & 0.21 & 0.59 & 0.21 & 0.64 \\
\hline 4 & - fodder & 1.41 & 3.49 & 1.02 & 2.16 & 1.45 & 3.62 \\
\hline 5 & -- field pea & 0.19 & 0.54 & 0.24 & 0.37 & 0.19 & 0.56 \\
\hline 6 & -- horse bean & 0.11 & 0.38 & 0.12 & 0.25 & 0.11 & 0.39 \\
\hline 7 & -- sweet lupine & 0.96 & 2.28 & 0.45 & 1.20 & 1.00 & 2.38 \\
\hline 8 & - pulse mixes with others & 1.36 & 1.23 & 0.82 & 0.83 & 1.41 & 1.27 \\
\hline 9 & Industrial crops & 17.40 & 16.78 & 6.21 & 6.02 & 18.46 & 17.77 \\
\hline 10 & Potatoes & 1.79 & 1.76 & 3.20 & 2.87 & 1.65 & 1.66 \\
\hline 11 & Fodder crops & 9.06 & 9.79 & 15.86 & 16.77 & 8.42 & 9.14 \\
\hline 12 & - grasses & 1.29 & 1.52 & 2.63 & 3.20 & 1.16 & 1.37 \\
\hline 13 & - pulses & 0.06 & 0.10 & 0.14 & 0.10 & 0.05 & 0.10 \\
\hline 14 & - papilionaceous & 0.44 & 0.70 & 0.74 & 1.02 & 0.41 & 0.67 \\
\hline 15 & Winter crops (in analysed year) & 55.14 & 54.13 & 41.64 & 40.79 & 56.42 & 55.37 \\
\hline 16 & Winter crops (for the next year) & 54.21 & 55.52 & 40.27 & 40.48 & 55.53 & 56.91 \\
\hline 17 & Catch crops & 2.54 & 5.15 & 2.00 & 1.66 & 2.60 & 5.48 \\
\hline 18 & - catch crops for green cover & 2.35 & 4.69 & 1.89 & 1.38 & 2.39 & 4.99 \\
\hline
\end{tabular}

Source: Own study based on FADN data.

Catch crops are another important EFA element. Their significance is due to their beneficial role in soil protection and improving soil structure. Catch crops can be also used as fodder. However, catch crops are a complementary element of the cropping pattern in Polish farms (in 2014, their share in the cropping pattern in an average farm was only $2.5 \%$ ). It should be noted, however, that the area under catch crops has rapidly increased in recent years (to 5.2\% in 2015). These changes occurred primarily in larger farms, obliged to maintain EFAs, while in smaller farms, this area slightly decreased (from $2.0 \%$ in 2014 to $1.7 \%$ in 2015). The change in the area of catch crops (positive in larger farms, negative in smaller ones) proves the effectiveness of the greening mechanism in encouraging farmers to maintain EFAs by using agricultural practices.

Summing up, the change in the structure of agricultural land use which occurred in the analysed farms satisfied greening requirements. In these farms, permanent grassland was maintained within the prescribed range. At the same time, the area of fallow land, which is the element of EFAs, was increased. The increase in the area of fallow land was recorded mainly in larger farms, whereby the increase in this area did not result in reducing the total sown area on arable land. Research shows that greening requirements applicable to land use have no adverse effects on farms' potential production capacity. Farmers that committed themselves to meet greening requirements did not reduce the area with production purpose. They slightly increased the area of arable land to meet both the production and environmental objectives. In other words, the production capacity of the analysed commercial farms did not decrease as a result of the introduction on the greening mechanism ${ }^{8}$.

As regards the crop diversification requirement, farms met in primarily by growing winter and spring crops. Already in 2014, i.e. before greening requirements were introduced, winter soil cover occupied half of the sown area, which confirms a favourable organization of plant production. Previously applicable legal regulations on crosscompliance and agri-environmental programmes that promoted good agricultural practices ensuring soil protection were undoubtedly of importance in this respect.

\footnotetext{
${ }^{8}$ Results of research performed based on econometric models (Czekaj, Majewski, Wąs, 2012; Czekaj, Majewski, Wąs, 2014), as well as public statistical data (Jaroszewska, Wąs 2017), also showed no effects of the greening mechanism on agricultural production.
} 
Taking into account the main groups of cultivated crops, plants improving soil structure are just the nominal part of sown crops, but their share in the cropping pattern grows rapidly, especially in larger farms. Smaller farms, despite of not being bound by the EFA requirement, were obliged to diversify crops, also with plants improving soil structure (nitrogen-fixing plants), while increasing the overall ecological focus area. Besides plants grown as the main crop, farmers cultivated catch crops, which also served an environmental role and were an important EFA element. In general, catch crops accounted for the small portion of total crop area, which was higher in larger farms. It seems that both farmers using smaller farms, i.e. ones with an arable land area of 10-15 ha, as well as these operating larger farms, easily adapted to the new requirements. These two groups of farms met most of the organizational requirements concerning plant production already in 2014. Minor organizational changes were necessary only in larger farms.

\section{Farms' typology}

In accordance with the FADN and EUROSTAT specifications, the following general types of farms (GTF classification) are identified, namely specialized in: 1 . field crops, 2. horticulture, 3. permanent crops, 4. rearing grazing livestock, 5. rearing granivores and non-specialised with: 6 . mixed crops, 7. mixed livestock, 8. with mixed crops and livestock (Goraj et al. 2012). The typology structure of the analysed farms is illustrated in Figure 1.

As shown Figure 1, farms maintaining EFAs (i.e. larger one) were specialized definitely more often in field crops (type 1) and simultaneously rarely in rearing grazing livestock (type 4) comparing with other analysed farms` groups. The opposite relation between these farming types was observed in the case of smaller farms. Farms required to meet only the crop diversification, i.e. these with an area of 10-15 ha of arable land, were specialized relatively less often in field crops (type 1) and more frequently in rearing grazing livestock (type 4), compared to the structure of larger farms and all analysed commercial ones. These results indicate that among larger farms with an arable land area of 15 ha and more, these are primarily farms specialized in field crops that are obliged to meet the major greening requirements, i.e. crop diversification and EFA maintenance.

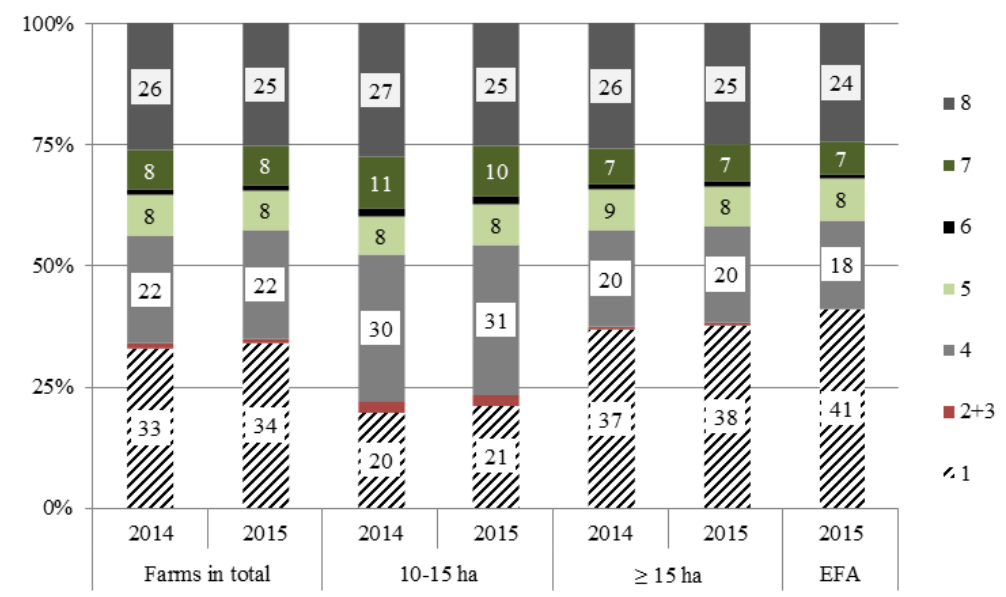

Figure 1. General farms` types General farms` types:

specialist in 1). field crops, 2). horticulture, 3). permanent crops, 4). rearing grazing livestock, 5). rearing granivores; and non-specialist with: 6). mixed crops, 7). mixed livestock, 8). with mixed crops and livestock. Source: Own study based on FADN data.

\section{EFA specification in 2015}

In 2015, total ecological focus area in farms keeping agricultural accounting was 15 thousand ha ${ }^{9}$, which accounted for $6.5 \%$ of arable land. This figure shows that the analysed farms fully complied with the requirement to maintain EFA (taking into account the result for the entire analysed farms` group). In accordance with applicable legal regulations, farms with an arable land area of 15 ha and more should set apart at least $5 \%$ of their areas for this purpose.

The applicable legislation specified many different elements of EFA, that are related to agriculture, forests and landscape ${ }^{10}$. In accordance with the specification, most of these elements concern landscape, while some of them are related to the organization of plant production, i.e. the use of catch crops and companion crops, as well as the cultivation of nitrogenfixing plants. The farmer can decide which elements are to be used to comply with the EFA requirement.

As indicated in Table 4, farmers concentrated on suitable plant production, adjusted to environmental requirements, and only few of them selected landscape and forest elements (these accounted for just a few percent of the total EFA). A total of $87 \%$ of the weighted ecological area was used for stubble catch crops and the cultivation of nitrogenfixing plants. Farmers did not diversify EFAs - one or two EFA types were selected most often on the farm level (which was done by $94 \%$ of farms). Farmers' choices related to meeting the EFA requirement by plants cultivation in the main crop and secondary crop translated into a change in the cropping pattern in their farms, thus improving water and soil

\footnotetext{
${ }^{9}$ This area refers to the weighted area. Due to different environmental significance of the various EFA elements (agricultural and landscape ones), an EFA weighted area is given (Ministry of Agriculture and Rural Development, 2016).

${ }^{10}$ See footnote 4.
} 
conditions. Results of the study may indicate indirectly a small share of valuable landscape elements relative to the agricultural land.

Table 4. The main EFA elements (in 2015)

\begin{tabular}{|c|r|r|r|r|r|r|}
\hline \multirow{2}{*}{ Elements } & \multicolumn{2}{|c|}{ Farms } & \multicolumn{4}{|c|}{ Surface EFA* } \\
\cline { 2 - 7 } & Number & \multicolumn{1}{c|}{ C } & C (ha) & W (ha) & W (\%) \\
\hline EFA14a: stubble catch crops & 2707 & 57.1 & 16749 & 5025 & 54.2 & 34.2 \\
EFA15: nitrogen-fixing crops & 2229 & 47.0 & 11173 & 7821 & 36.1 & 53.2 \\
EFA14b: winter catch crops & 275 & 5.8 & 1610 & 483 & 5.2 & 3.3 \\
EFA1: fallow land & 228 & 4.8 & 804 & 804 & 2.6 & 5.5 \\
\hline EFA in total & 4744 & $\mathrm{x}$ & 30910 & 14699 & 100 & 100 \\
\hline
\end{tabular}

* Surface: $C$ - under conversion, W-weighed.

Source: Own study based on FADN data.

\section{The main farms' outcomes}

Analysing the effects of greening on the operation of farms, it is important to consider their economic conditions. The change in the organization of agricultural production in the analysed farms in 2015, as compared to 2014, concerned mainly the patterns of field crops, ensuring the farms' adaptation to new legal constraints. It should be noted, that the scope of introduced changes was minor due to their favourable (environmental) organization in 2014. The production and economic outcomes in these farms did not indicate significant differences in the analysed period (Table 5). Both smaller farms (10-15 ha of arable land) and larger ones (arable land area of 15 ha and more) generated similar values of production and income in the years, that were compared. Similar relations occurred in the case of productivity and profitability indicators of agricultural production factors. In 2015, the value of total output in the average farm was EUR 66 thousand and family farm income amounted to EUR 22 thousand ${ }^{11}$.

A different approach needs to be adopted to evaluate changes in the amounts of external transfers, i.e. subsidies received by these farms. The amount of subsidies granted to farms in 2015 was significantly higher than in 2014 , as it increased by $18 \%$. This increase caused both farmers' activity and changes in the criteria for accessing rural development measures and direct payments, including the area eligibility for the single area payment scheme. It needs to be noted, that in 2015 - the first year of greening implementation - only the small part of beneficiaries actually received payments in this regard. An administrative decision under which farmers were granted by direct payments advances at the end of 2015 (i.e. much earlier than in previous years) is of importance in this respect (Ministry of Agriculture and Rural Development, 2015). In previous period, these payments were made usually in the following year ${ }^{12}$. Summing up, the increase in the amount of transfers was mainly the effect of administrative decisions (granting advances for direct payments, the scope and criteria of direct support), whereas farmers' incentive was supplement determinant.

Table 5. Outcomes, subsidies and their relation*

\begin{tabular}{|c|c|c|c|c|c|c|c|c|c|c|}
\hline \multirow{2}{*}{ No. } & \multirow{2}{*}{ Specification } & \multirow{2}{*}{2014} & \multirow{2}{*}{2015} & $15 / 14$ & 2014 & 2015 & \multirow{2}{*}{\begin{tabular}{|c|}
$15 / 14$ \\
$\%$
\end{tabular}} & 2014 & 2015 & \multirow{2}{*}{$\begin{array}{c}15 / 14 \\
\%\end{array}$} \\
\hline & & & & $\%$ & \multicolumn{2}{|c|}{$10-15$ ha } & & \multicolumn{2}{|c|}{$\geq 15 \mathrm{ha}$} & \\
\hline 1 & Total Output (EUR/farm) & 70019 & 65954 & 94 & 33256 & 31477 & 95 & 80836 & 76098 & 94 \\
\hline 2 & Total Output (EUR/ha) & 1587 & 1484 & 94 & 1726 & 1647 & 95 & 1572 & 1467 & 93 \\
\hline 3 & Total Output (EUR/AWU) & 34942 & 33154 & 95 & 18482 & 17623 & 95 & 39164 & 37138 & 95 \\
\hline 4 & Gross Farm Income (EUR/farm) & 34623 & 34339 & 99 & 16339 & 16557 & 101 & 40003 & 39571 & 99 \\
\hline 5 & m Income (EUR/ha) & 785 & 773 & 98 & 848 & 866 & 102 & 778 & 763 & 98 \\
\hline 6 & Gross Farm Income (EUR/ & 17278 & 17262 & 100 & 9080 & 9270 & 102 & 19381 & 19312 & 100 \\
\hline 7 & Income (EUR/farm) & 22363 & 21673 & 97 & 10359 & 10432 & 101 & 25895 & 24980 & 96 \\
\hline 8 & Incol & 507 & 488 & 96 & 538 & 546 & 102 & 503 & 481 & 96 \\
\hline 9 & (EUR/FWL & 12630 & 12318 & 98 & 6110 & 6228 & 102 & 14444 & 14000 & 97 \\
\hline 10 & D & 784 & 13877 & 118 & 5146 & 5938 & 115 & 13737 & 16213 & 118 \\
\hline 11 & $\mathrm{C}$ & 10632 & 12671 & 119 & 4701 & 5467 & 116 & 12378 & 14791 & 119 \\
\hline 12 & $\mathrm{D}$ & 7453 & 9956 & 134 & 3542 & 4425 & 125 & 8604 & 11584 & 135 \\
\hline 13 & Single & 6579 & 8490 & 129 & 2945 & 3637 & 123 & 7648 & 9918 & 130 \\
\hline 14 & Current Subsidies & 90 & 91 & $1 \mathrm{pp}$ & 91 & 92 & $1 \mathrm{pp}$ & 90 & 91 & $1 \mathrm{pp}$ \\
\hline 15 & Direct Payments/Subsidies (\%) & 63 & 72 & $9 \mathrm{pp}$ & 69 & 75 & $6 \mathrm{pp}$ & 63 & 71 & $8 \mathrm{pp}$ \\
\hline 16 & Single Area Payments/Subsidies (\%) & 56 & 61 & $5 \mathrm{pp}$ & 57 & 61 & $4 \mathrm{pp}$ & 56 & 61 & $5 \mathrm{pp}$ \\
\hline 17 & Subsidies/Output (\%) & 17 & 21 & $4 \mathrm{pp}$ & 15 & 19 & $4 \mathrm{pp}$ & 17 & 21 & $4 \mathrm{pp}$ \\
\hline 18 & Subsic & 53 & 64 & $11 \mathrm{pp}$ & 50 & 57 & $7 \mathrm{pp}$ & 53 & 65 & $12 \mathrm{pp}$ \\
\hline 19 & Balance Subsidies and Taxes/Income (\%) & 38 & 49 & $11 \mathrm{pp}$ & 38 & 46 & $8 \mathrm{pp}$ & 38 & 49 & $11 \mathrm{pp}$ \\
\hline
\end{tabular}

*1 FWU (Family Work Unit) is the equivalent of a full-time labour of a farming family member. All production and economic categories are explained in (Floriańczyk, Osuch, Plonka 2017). Current subsidies - total subsidies excluding on investment. PP - percentage points. Values presented in current prices.

Source: Own study based on FADN data.

\footnotetext{
${ }^{11}$ According to FADN data, the average exchange rate in 2015 was EUR $1=$ PLN 4.13.

${ }^{12}$ Advances for direct payments were disbursed for the first time in 2015 . $50 \%$ of advances were disbursed for the single area payment, additional payment, protein crop premium and soft fruit payment. A total of about $80 \%$ of beneficiaries covered with direct support were paid advances for these payments (Ministry of Agriculture and Rural Development, 2016).
} 
In 2015, the average farm received subsidies in the amount of EUR 14 thousand. More than $90 \%$ of this amount was associated with the farm's operating activity. In 2014-2015, the inflow of funds under direct payments increased significantly (to as much as 34\%), which was largely the effect of the single area payment increase (by 29\%), caused by earlier transfer of advance payment. Comparing farms with different arable land surface, there should be noted, that larger farms (with an arable land area of 15 ha or more) demonstrated a more favourable subsidy absorption rate (of direct payments in total and single area payments) compared to smaller farms. In the case of larger farms, this was an increase by 35 and $30 \%$, while in smaller ones - by 25 and $23 \%$, respectively in analysed years.

Comparing the situation in 2015 to that in 2014, there is observed increasing importance of external funds in determining the farms` economic situation, that provided e.g. the higher ratio value of subsidies to their output. This ratio increased in the analysed years from $17 \%$ to $21 \%$. In 2015 , almost half of farms' income came from this revenue source, while in 2014, 38\% (taking into account tax liabilities as well). This ratio and its growth rate was higher in the case of larger farms, i.e. these with an arable land area of 15 ha and more, compared to farms with a smaller area. The presented figures indicated that funds in the form of subsidies became important determinant of farms' outcomes, especially in the case of larger ones. This phenomenon has enhanced recently.

\section{THE MAIN CONCLUSIONS}

1. With the introduction of the greening mechanism, farms with an arable land area of 15 ha and more took the most intense organizational action to meet new administrative requirements.

2. The production capacity of the analysed FADN farms did not decrease after the greening mechanism introduction. Farmers combined production objectives with environmental ones, that was the result of farms proper organization and enlarging agricultural land, also fallow land - the important EFA element.

3. Preserving status quo in farms (as regards area under winter crops and area of permanent grassland) or introduction of desirable organizational changes (relating to the maintenance of EFAs, also through catch crops, cultivation of plants that improve soil structure, maintenance of fallow land) are the essence of action taken in the analysed farms in the context of greening.

4. Formally, the scope of greening requirements is diversified by the type and area of agricultural land in the farm. As indicated the analysed farms' typology, farms specialised in field crops the most frequent should meet both crop diversification and EFA requirements.

5. The maintenance of EFAs in farms primarily requires appropriate organization of plant production. Ecological focus areas in the analysed farms are predominantly agricultural ones, which determines the need for agricultural practices continuation to ensure the desired cropping pattern.

6. The scope of changes introduced in plant production referring to the greening requirements was insignificant and concerned mainly larger farms (with arable land area of 15 ha and more). Farmers introduced the required organizational changes smoothly, mainly by increasing area under leguminous and papilionaceous plants.

7. The environment-friendly farms' organization before greening introduction facilitated their adaptation in 2015 .

8. Between 2014-2015, farms' production and economic outcomes, both smaller and larger ones, were comparable. Meanwhile, the stream of subsidies significantly increased, especially in the case of larger farms.

9. The increase in subsidy transfer mainly resulted from administrative decision (earlier advance payment of direct support), whereas increased farmers' engagement had secondary importance. These changes cannot be associated with the greening mechanism implementation.

10. In the first year of greening implementation, these requirements didn't affect negatively the farms' production and economic results, since the determined ecological area was nominal and crop diversification criteria didn't necessitate major organizational changes in agricultural production. In the long run, environmental effects of greening should counteract degradation of natural resources as a result of agricultural activity and improve soil and water conditions, as well as increase soil productivity.

\section{REFERENCES}

1. Agency for Restructuring and Modernisation of Agriculture. 2015. Płatności bezpośrednie w roku 2015 [Direct payments in 2015], ARiMR, Warsaw. [In Polish]

2. Agency for Restructuring and Modernisation of Agriculture (b). 2015. Zazielenienie. Rolniku! Sprawdź, co to dla Ciebie oznacza [Greening. The farmer! Check out what this means for you!], ARiMR, Warsaw. [In Polish]

3. Czekaj, S., Majewski, E., Wąs, A. 2012. Oszacowanie skutków zazielenienia Wspólnej Polityki Rolnej UE w Polsce w perspektywie 2014 roku na przyktadzie zbiorowości gospodarstw FADN [To estimate the effects of greening the EU Common Agricultural Policy in Poland in the perspective of 2014 on tha basis of FADN], [In] Dopłaty bezpośrednie i dotacje budżetowe a finanse oraz funkcjonowanie gospodarstw i przedsiębiorstw rolniczych [Direct payments and budget subsiedies vs. finance and farms`and Agricultural enterprices`organization], ed. J. Kulawik, Raport Programu Wieloletniego 2011-2014, No. 46, IERiGŻPIB, Warsaw. [In Polish]

4. Czekaj, S., Majewski, E., Wąs, A. 2014. Impact of the CAP new greening on the economic results of the Polish farms. Zagadnienia Ekonomiki Rolnej, No. 341(Sup 4), pp. 105-121.

5. Direct Payments Department, Ministry of Agriculture and Rural Development. 2016. Materiał informacyjny dotyczący płatności w tytułu praktyk rolniczych korzystnych dla klimatu i środowiska (zazielenienie) [Information material concerning payments linked with agricultural practices beneficial for the climate and the environment (greening)], MRiRW, Warsaw. [In Polish] 
6. European Commission. 2016. Commission staff working document. Review of greening after one year. SWD(2016) 218 final PART $1 / 6$, Brussels.

7. European Commission. 2017. Sprawozdanie komisji dla Parlamentu Europejskiego i Rady w sprawie wdrażania obowiązku w zakresie obszarów proekologicznych $\mathrm{w}$ ramach systemu płatności bezpośrednich $\mathrm{z}$ tytułu zazielenienia [Report from the Commission to the European Parlament and the Council on the implementation of the obligation in terms of ecological focus areas under the direct payment scheme for the greening], $\operatorname{COM(2017)} 152$ final, Bruseles.

8. Floriańczyk, Z., Osuch, D., Płonka, R. 2017. 2015. Standard Results of Polish FADN agricultural holdings, IERiGŻ-PIB, Warsaw.

9. Goraj, L., Bocian, M., Cholewa, I., Nachtman, G., Tarasiuk, R. 2012. Współczynniki Standardowej Produkcji “2007” dla celów Wspólnotowej Typologii Gospodarstw Rolnych [The coefficients of Standard Output "2007" for the purposes of the Community Typology for agricultural holdings], IERiGŻ-PIB, FADN, Warsaw. [In Polish]

10. Hart, K. 2015. Green direct payments: implementation choices of nine Member States and their environmental implications. IEEP, London.

11. Hart, K, Baldock, D., Buckwell, A. 2016. Learning the lessons of the Greening of the CAP. IEEP, London.

12. Jaroszewska, J., Wąs, A. 2017. Wpływ zazielenienia WPR na strukturę zasiewów w polskim rolnictwie [The effect of the CAP greening on the sown structure in Polish agriculture]. Economik University in Wrocław. In publishing. [In Polish]

13. Kociszewski, K. 2014. Ekologiczne aspekty zmian Wspólnej Polityki Rolnej a zrównoważony rozwój polskiego rolnictwa [Ecological aspects of the CAP changes and sustainable development of Polish agriculture], [In] Z badań nad rolnictwem społecznie zrównoważonym [23] [The research on sustainable agriculture [23]]. ed. J.St. Zegar. Raport No. 100.Warsaw: IERiGŻ-PIB. 124-157. [In Polish]

14. Krzyżanowski, J. 2015. Wpływ WPR 2014-2020 na zrównoważenie polskiego rolnictwa w świetle dotychczasowych badań i bieżących dokumentów, [In] Z badań nad rolnictwem społecznie zrównoważonym [31][ The impact of the CAP 2014-2020 on sustainability of Polish agriculture in the light of existing research and current documents, [In] The research on sustainable agriculture [31], ed. J.St. Zegar, Raport No. 6, IERiGŻ-PIB, Warsaw, pp. 89-115. [In Polish]

15. Mauerhofer,V., Hubacek, K., Coleby, A. 2013. From polluter pays to provider gets: distribution of rights and costs under payments for ecosystem services. Ecology and Society, No. 18(4), p. 41. https://doi.org/10.5751/ES-06025-180441

16. Ministry of Agriculture and Rural Development. 2015. Rolnictwo i gospodarka żywnościowa w Polsce [Agriculture and food industry in Poland. Warsaw], MRiRW, Warsaw. [In Polish]

17. Ministry of Agriculture and Rural Development. 2016. Rolnictwo i gospodarka żywnościowa w Polsce. [Agriculture and food industry in Poland. Warsaw], ed. IERiGZ-PIB. MRiRW. [In Polish]

18. Ministry of Agriculture and Rural Development. 2014. Rural Development Programme for 2014-2020, see: http://www.minrol.gov.pl/Wsparcie-rolnictwa/Program-Rozwoju-Obszarow-Wiejskich-2014-2020. [In Polish]

19. Official Journal of the European Union. 2007. Council Regulation (EC) No 834/2007 of 28 June 2007 on organic production and labelling of organic products and repealing Regulation (EEC) No 2092/91. L 189/1.

20. Official Journal of the European Union. 2013. Regulation (EU) No 1307/201 of the European Parliament and of the Council of 17 december 2013 establishing rules for direct payments to farmers under support schemes within the framework of the common agricultural policy and repealing Council Regulation (EC) No 637/2008 and Council Regulation (EC) No 73/2009. L 347/608.

21. Official Journal of the European Union. 2014. Regulation (EU) No 639/2014 of 11 March 2014 supplementing Regulation (EU) No 1307/2013 of the European Parliament and of the Council establishing rules for direct payments to farmers under support schemes within the framework of the common agricultural policy and amending Annex X to that Regulation.

22. Wrzaszcz, W. 2017. Skutki zazielenienia WPR na przykładzie gospodarstw prowadzących rachunkowość rolną [The greening effects of the CAP on the example of agricultural accounting farms]. SERiA Annals, Vol. XIX/4, pp. 331-337. 